\title{
Bioremediation of biomethanated distillery effluent before discharge to reduce contamination of aquatic sources
}

\author{
S. N. Agnihotri
}

Padmashree Dr. D.Y. Patil Arts, Commerce and Science College, Pimpri, Pune, Maharashtra, India

\begin{abstract}
The effluents from distilleries which contain colored pigments such as Melanoidin, Caramel and Alkaline Degradation Products (ADP) responsible for its dark brown color, high-suspended solids, high concentration of Chemical Oxygen Demand (COD) and Biological Oxygen Demand (BOD), besides causing aesthetic damage to nearby aquatic sources, are toxic to resident flora and fauna. Anaerobic digestion (Biomethanation) of effluents containing Molasses Spent Wash is one of the treatments followed by distilleries and the resulting dark brown sludge is used as a fertilizer. The effluent after such treatment reduces COD and BOD but is still dark brown in color and is a major problem with distilleries. This paper reports that Aspergillus oryzae JSA-1, the natural isolate from soil could decolorize the undiluted biomethanated effluent (BME) effectively by simple adsorption and proved to possess a very high potential in bioremediation of different BME samples. In the study of bioremediation of BME by the column chromatography technique using fungal biomass of Aspergillus oryzae JSA-1 as a matrix, it was found that the fungal biomass could effectively reduce the total color $(99.16 \pm 0.09 \%)$ of $\mathrm{BME}$ samples as well as could reduce most of the important pollution parameters such as COD $(90.78 \pm 0.22 \%)$, sulphates $(92.75 \pm 0.12 \%)$, metals like iron $(95.77 \pm$ $0.17 \%)$, copper $(79.59 \pm 0.08 \%)$ and total dissolved solids i.e. TDS $(75.59 \pm$ $0.05 \%$ ) efficiently by biosorption phenomenon.
\end{abstract}

Keywords: bioremediation, fungal culture, melanoidin, decolorization, biomethanation, distillery effluent, fungal biosorption, chromatography. 


\section{Introduction}

The effluents from distilleries contain large amounts of molasses spent wash (MSW) which pollutes aquatic ecosystems due to its intense brown color which cuts off light, prevents photosynthesis and causes anaerobic conditions. Next to effluent from paper and pulp mill and tannery, molasses spent wash is a major environmental hazard to land or aquatic sources where they are discharged. Due to the importance attached to prevention of environmental pollution, environmental agencies all over the world are imposing strict regulations for mitigation of pollution from industries. Color removal in such effluents using terrestrial fungi has been reported. Fungi are recognized for their superior aptitudes to produce a large variety of extracellular proteins, organic acids and other metabolites, and for their capacities to adapt to severe environmental constraints $[1,2]$. For example, Aspergillus niger is the prototypical fungus for the production of citric acid [3 to 5], homologous proteins (especially enzymes) and heterologous proteins [6 to 10]. Moreover, Phanerochaete chrysosporium is the model of white-rot fungi for the production of peroxidases $[11,12]$. Beyond the production of such relevant metabolites; fungi have been attracting a growing interest for the biotreatment (removal or destruction) of wastewater ingredients such as metals, inorganic nutrients and organic compounds [13-17]. Filamentous fungi show their decolorizing activity in following ways which are due to decomposition by an intracellular enzyme system via production of active oxygen from hydrogen peroxide $[18,19]$ and/ or the adsorption of coloring components by mycelia [20], especially for the decolorization of melanoidin. The adsorption of melanoidin is the first step of melanoidin decomposition mechanism in microorganisms and in case of Aspergillus oryzae Y2-32, due to lack of a melanoidin decolorizing enzyme, the mechanism of decolorization does not continue further [20]. In the present study biomass based decolorization was carried out by successive column chromatography of BME through the biomass of Aspergillus oryzae JSA-1.

\section{Materials and methods}

\subsection{Isolation and identification of microbial culture efficient in decolorizing biomethanated distillery effluent}

Soil samples were collected from the nearby vicinity of biomethanation plants located in Pune District, in India. These soil samples were screened for growth of micro-organisms showing activity of decolorization of biomethanated distillery effluent. On primary screening twenty fungal strains showed visual decolorization activity on solid medium containing biomethanated distillery effluent. Therefore as the secondary screening, the decolourization activities of these strains in liquid medium with biomethanated distillery effluent, under shaking conditions were examined. Out of these, one strain was found to give maximum decolorization of biomethanated distillery effluent i.e. up to $68 \%$. Identification of the selected strain was carried out by the standard methods with 
respect to morphological, cultural, physiological and biochemical characterization [21]. This strain was named Aspergillus oryzae JSA-1 and was chosen for subsequent experiments of decolorization. The culture was sub cultured and maintained on potato dextrose agar at $4{ }^{0} \mathrm{C}$ in the refrigerator.

\subsection{Collection of different biomethanated effluent samples.}

Biomethanated effluent samples were obtained from anaerobic treatment plants set up at four different molasses distilleries in Neera, Pravara, Rahuri and Sanjeevani (Maharashtra state, India). The samples were centrifuged at $10,000 \mathrm{rpm}$ for 30 minutes and refrigerated at $4^{\circ} \mathrm{C}$ to avoid further oxidation.

\subsection{Preparation of biomass of Aspergillus oryzae JSA-1}

The medium used for the biomass production contained glycerol $5 \%$, peptone $0.5 \%$, potassium dihydrogen phosphate $0.1 \%$, magnesium sulphate $0.05 \%$ and distilled water. The initial $\mathrm{pH}$ of the medium was adjusted to 6 . The medium was dispensed in $200 \mathrm{ml}$ aliquots in $500 \mathrm{ml}$ conical flasks and sterilized at $121^{\circ} \mathrm{C}$ for 20 minutes. The sterile medium was inoculated with the culture $\left(10^{7}\right.$ spores $/ 100$ $\mathrm{ml}$ medium) and incubated at $30^{\circ} \mathrm{C}$ on the incubator shaker at $150 \mathrm{rpm}$ for eight days. The mycelial biomass was harvested by vacuum filtration through four layers of cheese cloth, washed extensively with double distilled water and dewatered homogenized biomass was used for further studies.

\subsection{Decolorization of biomethanated distillery effluent by mycelial biomass of Aspergillus oryzae JSA-1 using column chromatography technique}

To study the decolorization of BME by bioadsorption mechanism using column chromatography technique, the fungal biomass of Aspergillus oryzae JSA-1 was prepared, washed extensively with double distilled water and was used to pack the glass columns (column size $10.5 \mathrm{~cm}$ x $3 \mathrm{~cm}$ ). A series of four columns were packed with each of 10 gm wet weight (dry weight $3.404 \mathrm{gm}$ ) of mycelia and packed columns were equilibrated with $0.1 \mathrm{M}$ acetate buffer of $\mathrm{pH} 4.5 .100 \mathrm{ml}$ of undiluted BME ( $\mathrm{pH}$ 4.5), was loaded on the first column and fraction was collected at a flow rate of $65 \mathrm{ml} /$ hour. The effluent fraction collected from each column, was further passed through next column serially (Figures 1 and 2). The fraction from last column as well as original BME loaded on the column were then analyzed for the reduction of pollution parameters such as total color, melanoidin, caramel, ADP, COD, TDS, phosphate, sulphate, chlorides, sodium, potassium, calcium, iron and copper by the standard methods for the examination of water and waste water [22, 23], (Table 1). The efficiency of Aspergillus oryzae JSA-1 to reduce color and COD by column chromatography technique was confirmed by passing different biomethanated effluent samples $(100 \mathrm{ml})$ separately through series of four columns loaded with the biomass in the similar way (Table 2, Figure 3). In order to optimize the process, similar experiments undiluted BME separately through the series of four columns loaded with fungal biomass of Aspergillus oryzae JSA-1 (Table 3). 


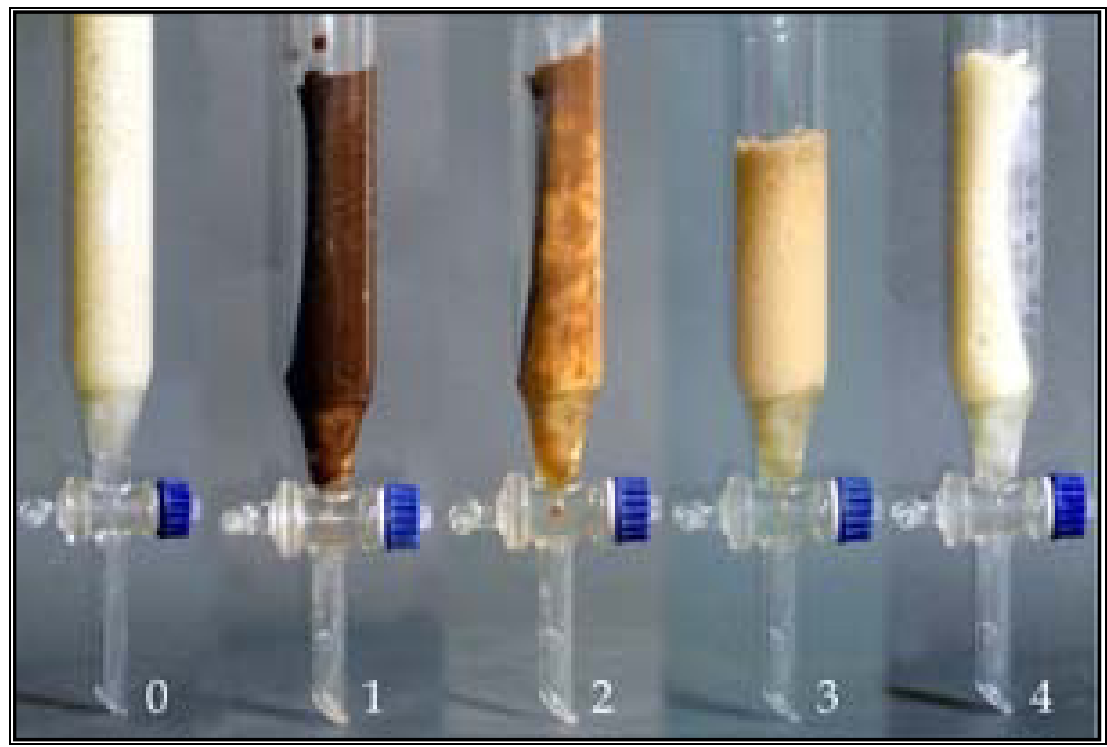

Figure 1: Glass columns packed with wet biomass of Aspergillus oryzae $J S A-1$ in column chromatography 0 - before passing the effluent through the packed biomass; $1-4$ - after passing the effluent serially from columns $1-4$, through the packed biomass.

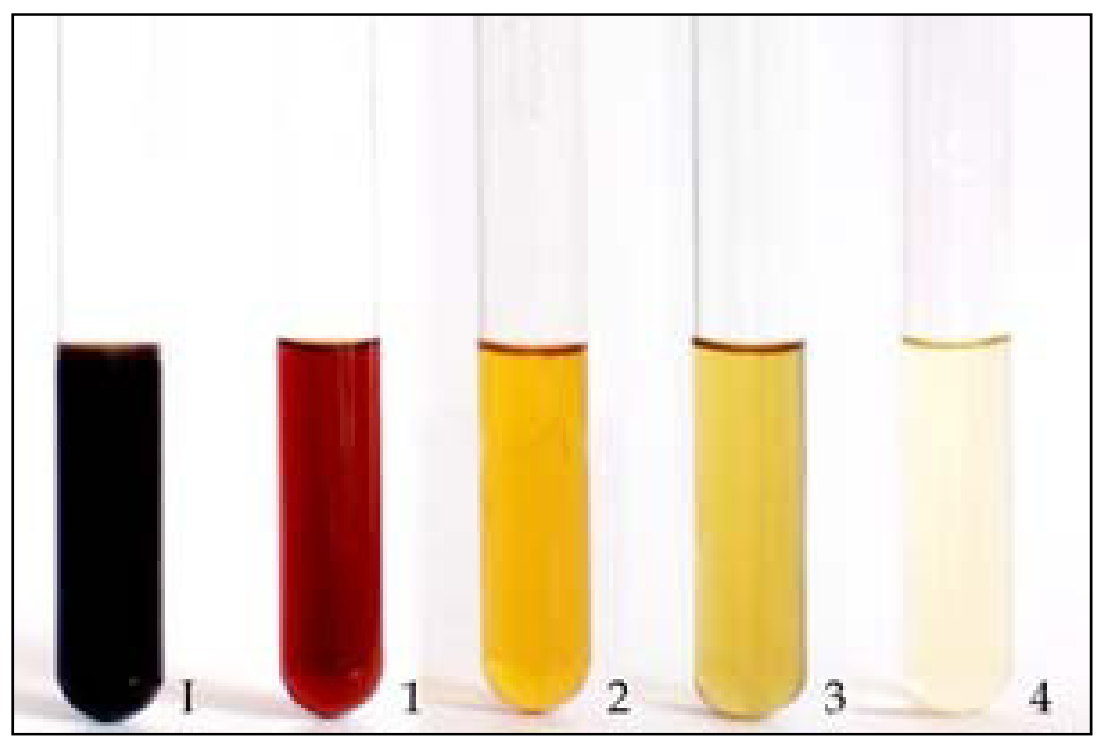

Figure 2: Color of effluent fractions; I - Effluent showing initial color; 1-4 - Effluent fractions showing color after passing through the packed biomass in series of four columns. 
Table 1: Chemical analysis and percent reduction of different pollution parameters in biomethanated effluent sample before and after column chromatography.

\begin{tabular}{|c|c||c|c|}
\hline \hline Parameters & Initial & Final & \% Reduction \\
\hline Color (O.D. 475) & 1.19 & 0.010 & $99.16 \pm 0.09$ \\
\hline Melanoidin (w/v \%) & 0.32 & 0.010 & $96.69 \pm 0.05$ \\
\hline \hline ADP (w/v \%) & 1.25 & 0.049 & $96.12 \pm 0.08$ \\
\hline \hline Caramel (w/v \%) & 1.9 & 0.07 & $96.30 \pm 0.02$ \\
\hline COD (ppm) & 20,400 & 1880 & $90.78 \pm 0.22$ \\
\hline TDS ( ppm) & 19,460 & 4750 & $75.59 \pm 0.05$ \\
\hline Phosphates (ppm) & 217.6 & 74.8 & $65.62 \pm 0.05$ \\
\hline \hline Sulphates (ppm) & 772.73 & 56.82 & $92.75 \pm 0.12$ \\
\hline Chlorides (ppm) & 3678.86 & 1359.58 & $63.04 \pm 0.13$ \\
\hline Sodium (ppm) & 345.4 & 62.8 & $81.82 \pm 0.24$ \\
\hline \hline Potassium (ppm) & 5030.9 & 3753.2 & $25.47 \pm 0.06$ \\
\hline \hline Calcium (ppm) & 320.00 & $<8$ & $97.81 \pm 0.32$ \\
\hline \hline Iron (ppm) & 3.67 & 0.155 & $95.77 \pm 0.17$ \\
\hline Copper (ppm) & 0.097 & 0.0198 & $79.59 \pm 0.08$ \\
\hline
\end{tabular}

\section{Results and discussion}

When the study on decolorization of biomethanated distillery effluent was carried out by column chromatography in a series of four columns using mycelium biomass of Aspergillus oryzae $J S A-1$ as a matrix, remarkable reduction in total color of the BME sample was seen column wise (Figures 1 and 2).

The results of chemical analysis of the effluent fraction collected from last column of the four columns in series, in the column chromatography are shown in Table 1. Melanoidin, ADP and caramel were found to be reduced by more than $96 \%$ and removal of total color was up to $99.16 \pm 0.09 \%$. Removal of COD was found to be up to $90.78 \pm 0.22 \%$. TDS was reduced to $75.59 \pm 0.05 \%$. Levels of all other parameters were also reduced effectively. Phosphates, sulphates and chlorides showed $65.62 \pm 0.05 \%, 92.75 \pm 0.12 \%$ and $63.04 \pm$ $0.13 \%$ reduction respectively. Sodium, potassium and calcium showed around 
$81.82 \pm 0.24 \%, 25.47 \pm 0.06 \%$ and $97.81 \pm 0.32 \%$ reduction and the trace elements like iron and copper also showed $95.77 \pm 0.17 \%$ and $79.59 \pm 0.08 \%$ reduction respectively.

The efficiency of Aspergillus oryzae JSA-1 to reduce color and COD by column chromatography technique by passing different biomethanated effluent samples $(100 \mathrm{ml})$ separately through series of four columns loaded with the biomass in the similar way has been shown in Table 2 .

The average percent reduction of color was around $72.33 \%$ after passing different undiluted effluent samples through first column which was increased to $92.90 \%, 97.53 \%$ and $98.90 \%$ in the effluent fractions of second, third and fourth column respectively. While the average percent reduction of COD in the effluent fraction of first column was around $65.73 \%$ which was increased to $79.16 \%$, $85.89 \%$ and $89.70 \%$ in the effluent fractions of second, third and fourth column respectively.

The reduction of color in different effluent samples after passing through the series of four columns is shown in Figure 3.

Table 2: $\quad$ Percent reduction in color and COD after column chromatography of different biomethanated effluent samples.

\begin{tabular}{|c|c|c|c|}
\hline $\begin{array}{c}\text { Undiluted } \\
\text { biomethanated } \\
\text { distillery effluent } \\
\text { sample }\end{array}$ & Column No. & $\begin{array}{c}\% \\
\text { Decolorization* }\end{array}$ & $\begin{array}{c}\% \\
\text { COD reduction* }\end{array}$ \\
\hline \multirow{4}{*}{ Neera } & 1 & $75.00 \pm 2.34$ & $69.23 \pm 1.31$ \\
\hline & 2 & $93.87 \pm 1.35$ & $82.26 \pm 1.24$ \\
\hline & 3 & $97.90 \pm 1.12$ & $87.51 \pm 1.03$ \\
\hline & 4 & $99.16 \pm 0.09$ & $90.78 \pm 0.22$ \\
\hline \multirow{4}{*}{ Pravara } & 1 & $70.12 \pm 1.82$ & $63.12 \pm 0.78$ \\
\hline & 2 & $93.75 \pm 0.79$ & $78.53 \pm 1.25$ \\
\hline & 3 & $96.68 \pm 1.02$ & $86.12 \pm 0.98$ \\
\hline & 4 & $98.24 \pm 0.53$ & $89.17 \pm 0.31$ \\
\hline \multirow{4}{*}{ Rahuri } & 1 & $76.76 \pm 2.41$ & $71.22 \pm 1.16$ \\
\hline & 2 & $93.76 \pm 1.11$ & $82.18 \pm 0.86$ \\
\hline & 3 & $97.97 \pm 0.98$ & $87.34 \pm 0.23$ \\
\hline & 4 & $99.22 \pm 0.34$ & $90.11 \pm 0.09$ \\
\hline \multirow{4}{*}{ Sanjeevani } & 1 & $67.43 \pm 1.75$ & $59.34 \pm 2.11$ \\
\hline & 2 & $90.20 \pm 1.21$ & $73.67 \pm 1.32$ \\
\hline & 3 & $97.57 \pm 0.63$ & $82.58 \pm 1.14$ \\
\hline & 4 & $98.96 \pm 0.43$ & $88.73 \pm 0.46$ \\
\hline
\end{tabular}

*With respect to original $\mathrm{BME}$. 


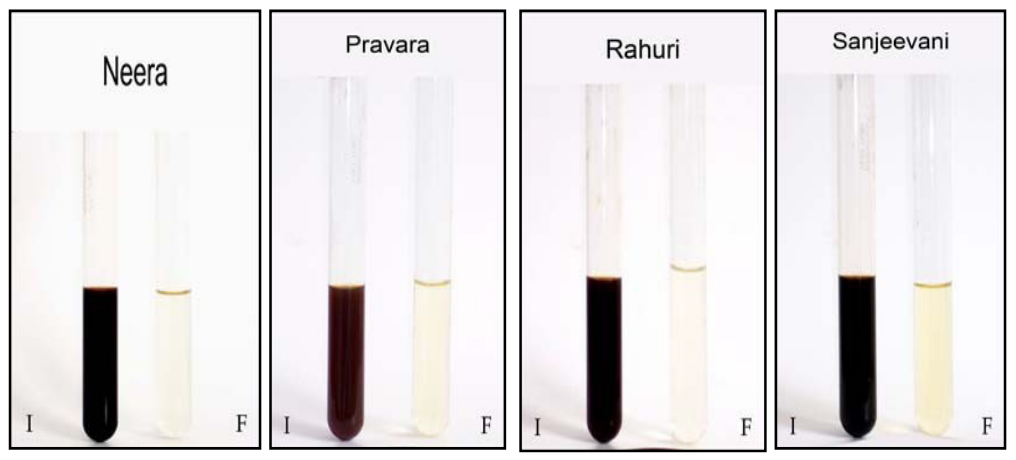

Figure 3: Reduction of color in different effluent samples after passing through series of four columns in column chromatography technique packed with the wet biomass of Aspergillus oryzae JSA1, A - Neera effluent, B - Pravara effluent, C - Rahuri effluent, D - Sanjeevani effluent (I: Initial color; F: Final color).

When the similar experiments were carried out by passing $200 \mathrm{ml}$ and $300 \mathrm{ml}$ of BME separately, to determine the percent reduction of color and COD, the percent reduction of color and COD was found to decrease with increase in amount of effluent loaded (Table 3).

Table 3: $\quad$ Percent reduction in color and COD after passing different volumes of effluent through a series of four columns.

\begin{tabular}{|c|c|c|c|}
\hline $\begin{array}{c}\text { Sr. } \\
\text { No. }\end{array}$ & $\begin{array}{c}\text { Volume of } \\
\text { undiluted } \\
\text { effluent loaded } \\
\text { on the column } \\
(\mathrm{ml})\end{array}$ & \% Decolorization & $\begin{array}{c}\text { \% COD } \\
\text { reduction }\end{array}$ \\
\hline 1 & 100 & $99.16 \pm 0.09$ & $90.78 \pm 0.22$ \\
\hline 2 & 200 & $82.35 \pm 1.15$ & $74.26 \pm 0.58$ \\
\hline 3 & 300 & $69.87 \pm 0.81$ & $63.32 \pm 0.63$ \\
\hline
\end{tabular}

When the amount of effluent loaded was increased from $100 \mathrm{ml}$ to $200 \mathrm{ml}$ and $300 \mathrm{ml}$, the average color removal varied from $99.16 \pm 0.09 \%$ to $82.35 \pm 1.15 \%$ and $69.87 \pm 0.81 \%$ respectively and the average COD removal decreased from $90.78 \pm 0.22 \%$ to $74.26 \pm 0.58 \%$ and $63.32 \pm 0.63 \%$ respectively.

\section{Conclusion}

Among the twenty fungal strains tested, the isolated strain of Aspergillus oryzae$J S A-1$ showed maximum efficiency of decolorization of biomethanated distillery 
effluent and it was found to be different in the morphological characterization as compared with the known strains of Aspergillus oryzae. Therefore the decolorization experiments on biomethanated distillery effluent were carried out using Aspergillus oryzae-JSA-1 for development of an efficient process for degradation of coloring compounds in distillery effluent.

From the study of column chromatography using fungal biomass as a matrix, it can be concluded that the fungal biomass of Aspergillus oryzae JSA-1 could effectively decolorize biomethanated effluent samples by biosorption phenomenon as well as could reduce some important pollution parameters such as COD, sulphates, metals (iron, copper) and TDS efficiently.

\section{References}

[1] Lilly, V. M., Barnett, H. L., 1951. Physiology of the fungi, McGraw Hill Book Co., 1st Edition. New York.

[2] Cochrane, V. W., 1958. Physiology of the fungi, John Wiley and Sons Inc., New York.

[3] Clark, D. S., 1962. Submerged citric acid fermentation of ferrocyanidetreated molasses: Morphology of pellets of Aspergillus niger, Can. J. Microbiol. 8: 133- 136.

[4] Lal, D. N., 1980. The influence of some ammonium compounds on the production of citric acid by Aspergillus niger AL. 29, Ind. J. Agri. Chem. 13: $153-157$.

[5] Grewal, H. S. and Kalra, K. L., 1995. Fungal production of citric acid, Biotechnol. Adv. 13: 209-234.

[6] Archer, D. B., Jeenes, D. J. and Mackenzie, D. A., 1994. Heterologous protein production from filamentous fungi, Antonie van Leeuwenhoek. 65: 245-250.

[7] Prasertsan, P., Kittikul, A. H., Maneesri, J., and Oi, S., 1997. Optimization for xylanase and cellulase production from Aspergillus niger ATTC 6275 in palm oil mill wastes and its application, World J. Microbiol. Biotechnol., 13: 555-559.

[8] Radzio, R. and Kuck, U., 1997. Synthesis of biotechnologicallyrelevant heterologous proteins in filamentous fungi, Process Biochem. 32: 529539.

[9] Wongwicharn, A., Harvey, L. M. and McNeil, B., 1999. Secretion of heterologous and native proteins, growth and morphology in batch cultures of Aspergillus niger B1-D at varying agitation rates, J. Chem. Technol. Biotechnol. 74: 821-828.

[10] Xu, J. F., Wang, L. P., Ridgway, D., Gu, T. Y. and Moo-Young, M., 2000. Increased heterologous protein production in Aspergillus niger fermentation through extracellular proteases inhibition by pellet growth, Biotechnol. Prog. 16: 222-227.

[11] Bumpus, J. A., Tien, M., Wright, D. and Aust, S. D., 1985. Oxidation of persistent environmental pollutants by white rot fungus, Science. 228: 1434-1436. 
[12] Rodriguez, E., Pickard, M. A. and Vazquez-Duhalt, R., 1999. Industrial dye decolorization by laccases from lignolytic fungi, Curr. Microbiol. 38: 27-32.

[13] Akthar, M. N., Sastry, K. S. and Mohan, P.M., 1996. Mechanism of metal ion biosorption by fungal biomass, Biometals. 9: 21-28.

[14] Field, J. A., de Jong, E., Feijoo, Costa G. and de Bont, JAM, 1993.Screening for ligninolytic fungi applicable to the degradation of xenobiotics, TiBtech.14: 44-49.

[15] Feijoo, G. and Lema, J. M., 1995. Treatment of forest industry effluents with toxic and recalcitrant compounds by the white rot fungi, Afinidad. 52: $171-180$.

[16] Palma, C., Moreira, M. T., Mielgo, I., Feijoo, G. and Lema, J. M., 1999. Use of a fungal bioreactor as a post treatment step for continuous decolorisation of dyes, Wat. Sci. Technol. 40: 131-136.

[17] Coulibaly, L., Naveau, H. and Agathos, S. N., 2002. A tanks-in- series bioreactor to simulate macromolecule laden wastewater pretreatment under sewer conditions by Aspergillus niger, Wat. Res. 36: 3941-3948.

[18] Ohmomo, S., Aoshima, I., Tozawa, Y., Sakurada, N. and Ueda, K.1985. Purification and some properties of melanoidin decolourizing enzymes, P III and P IV from mycelia of Coriolus versicolor Ps4a, Agric. Biol. Chem. 49, 2047-2053.

[19] Ohmomo, S., Kaneko, Y., Sirianuntapiboon, S., Somchai, P. and Atthasampunna, P., 1987. Decolourization of molasses waste water by a thermophilic strain, Aspergillus fumigatus G-2-6, Agric. Biol. Chem. 51(12), 3339-3346.

[20] Ohmomo, S., Kainuma, M., Kamimura, K., Sirianuntapiboon, S., Aoshima, I. and Atthasampunna, P., 1988. Adsorption of melanoidin to the mycelia of Aspergillus oryzae Y-2- 32, Agric. Biol. Chem. 52, 381.

[21] Collins, C.H. and Lyne, M.P., 1976. Microbiological methods, Butterworths Company Limited, London

[22] Standard methods for the examination of water and wastewater. 1998. $20^{\text {th }}$ Edition, Edited by Greenbers, A. E., Clesceri, L. S. and Eaton, A. D., APHA, AWWA and WEF, Washington D.C.

[23] Standard methods for the examination of water and wastewater, 01-sep2005, 21st edition, Greenberg, Arnold, et al, American Water Works Association/1368 pages, ISBN: 0875530478. 